\title{
Wild edible plant species used in the Ağrı province, eastern Turkey
}

\author{
Zakine KADIOGLU ${ }^{1}$, Kemal CUKADAR ${ }^{2}$, Nalan Nazan KALKAN ${ }^{3}$, Huseyin VURGUN ${ }^{4}$, Ozkan KAYA ${ }^{5 *}$ \\ Erzincan Horticultural Research Institute, 24060 Erzincan, Turkey. \\ *Correspondence: kayaozkan25@hotmail.com \\ ${ }^{1}$ https://orcid.org/0000-0003-2727-6771, ${ }^{2}$ https://orcid.org/0000-0003-1395-0964 \\ ${ }^{3}$ https://orcid.org/0000-0002-9204-7281, ${ }^{4}$ https://orcid.org/0000-0001-5871-8873 \\ ${ }^{5}$ https://orcid.org/0000-0002-1679-6125
}

\begin{abstract}
Wild edible plant species found in Ağrı are nutritionally and economically relevant. Plants are collected by the villagers and brought to the market for sale in the spring. Interest in these plants responds to the increasing demand for organic and natural food. In this study, 350 indepth face-to-face interviews with villagers about the edible plants used in Ağr1 (7 districts, 35 villages) were conducted in the region from April 2016 to October 2017. The species, parts used and their consumption and preservation techniques were analyzed and documented. Some of the wild edible plant species are consumed cured or canned, raw or cooked, dried, and some are frozen. The collected 100 wild edible species belong to 25 different plant families. Species are consumed as vegetables (91), spices (19), beverages (16), subterranean parts (5), fruits (3), seeds (3) and exudates (2). The most important species according to their cultural importance were: Amaranthus retroflexus, Beta trigyna, Gundelia tournefortii, Mentha longifolia, Polygonum persicaria, Rumex scutatus, Tragopogon porrifolius subsp. longirostris, and Urtica dioica. Leaves and young shoots were the most frequently used parts. Our study shows that wild edible plants are still well known and used by the local people of Ağrı as a food source. The documented data on these plants herein could be used as baseline information for further investigations on nutritional contents, as they could have the potential to become valuable nutrition sources.
\end{abstract}

Keywords. Ethnobotany, local names, modes of use, vegetables, wild plants.
Resumen. Las plantas silvestres comestibles que se encuentran alrededor de Ağrı siguen siendo importantes para la alimentación y la economía local. Estas plantas son recolectadas por la población local y vendidas en el mercado en primavera. El interés por las plantas silvestres comestibles ha aumentado debido a la creciente demanda de alimentos orgánicos y naturales. En este estudio se realizaron 350 entrevistas cara a cara entre abril de 2016 y octubre de 2017 a habitantes de la región de Ağrı (7 distritos, 35 pueblos). Se analizaron y documentaron las especies empleadas, la partes comestibles y sus modos de preparación, conservación y consumo. La mayoría se consumen, pero también se toman crudas. También se procesan en forma de conservas, se secan o se congelan. Las 100 especies registradas pertenecen a 25 familias y se usan como verduras (91), condimentos (19), bebidas (16), órganos subterráneos (5), frutos (3), semillas (3 ) y exudados (2). Según su importancia cultural, las plantas más importantes son: Amaranthus retroflexus, Beta trigyna, Gundelia tournefortii, Mentha longifolia, Polygonum persicaria, Rumex scutatus, Tragopogon porrifolius subsp. longirostris, y Urtica dioica. Las hojas y brotes jóvenes son las partes más utilizadas. Estos resultados muestran que las plantas silvestres comestibles todavía son muy conocidas y utilizadas por la población local de Ağrı como fuente de alimento. Además, los datos recopilados sobre estas plantas podrían usarse para futuras investigaciones sobre sus contenidos nutricionales, ya que tienen el potencial de convertirse en valiosas fuentes de nutrientes.

Palabras clave. Etnobotánica, modos de uso, nombres locales, plantas silvestres, verduras.

How to cite this article: Kadioglu Z., Cukadar K., Kalkan N.N., Vurgun H. \& Kaya O. 2020. Wild edible plant species used in the Ağrı province, eastern Turkey. Anales del Jardín Botánico de Madrid 77: e098. https://doi.org/10.3989/ajbm.2554

Title in Spanish: Plantas silvestres comestibles en la provincia de Ağrı, Turquía oriental.

Associate Editor: Manuel Pardo-de-Santayana. Received: 14 April 2020; accepted: 28 September 2020; published online: 21 December 2020.

\section{INTRODUCTION}

Edible plants that are gathered in the wild to be consumed as a drink or food have been an integral part of millions of people in rural and even urban regions in many developed countries around the world (Block 1991; Heinrich \& al. 2006; Leonti \& al. 2006; Behre 2008; Łukasz 2010; Hummer 2013; Schulp \& al. 2014; Reyes-García \& al. 2015). Indeed, wild edible plants have been reported to be sources of folic acid, vitamin, minerals, carotenoids, and other valuable chemical substances, some of them with antioxidant activity (Hasler 2002; Pieroni \& al. 2002; Ogle \& al. 2003; Tapsell \& al. 2006). Wild edible plants are also more likely to be free of herbicide and pesticide residues than cultivated plants. Previous studies suggest that the effects of wild edible plant resources on peoples' health are still little known and that their consumption and gathering have been reduced both in diversity of species and quantity (Millennium Ecosystem Assessment 2005; Tardío \& al. 2006; Łukasz 2013; Reyes-Garcia \& al. 2015; Bharucha \& Pretty 2010; Pardo-de-Santayana \& al. 2007). This decrease in wild plants use is related to urbanization and associated rural migration, modernization of lifestyles, industrialization of food production, and extinction of natural plant habitats, among others (Pardo-de-Santayana \& al. 2005; Turner \& Turner 2008; Bharucha \& Pretty 2010; Kalle \& Soukand 2013; Łukasz \& al. 2013; Abbet \& al. 2014; ReyesGarcía \& al. 2015). 
Ethnobotanical studies on European wild edible plants have been mainly conducted in the Mediterranean region (Ertuğ 2004; Tardío \& al. 2006; Rivera \& al. 2007; Pieroni $\&$ al. 2008; Blanco-Salas \& al. 2019). All these investigations clearly indicate that wild leafy vegetables or wild culinary herbs still represent a relevant part of the local or territorial Mediterranean diet in rural areas. Furthermore, their nutritional constituents have been studied in numerous publications showing relevant human health benefits (Guil Guerrero \& al. 1998; Trichopoulou \& al. 2000; Couladis \& al. 2003; Pieroni \& al. 2002; Tarwadi \& Agte 2003; Zeghichi \& al. 2003).

However, deep changes in feeding habits of people living in the Mediterranean rural areas have occurred and many local or traditional dietary models have already been forgotten, especially in situations where environmental and cultural transformations have led to changes in local diets (Tumino \& al. 2002), and thus local people have lost their plant knowledge over time. Therefore, studies on traditional food culture should be urgently implemented. This goes particularly for those regions in countries like Turkey, where, for historical and geographical reasons, have remained relatively isolated and local food uses are still alive but at risk of disappearing (Kadıŏlu \& al. 2020).

Turkey, at the crossroads between Europe and Asia, has a very rich flora in terms of wild food plants and several ethnobotanical studies have been conducted in various regions (e.g., Özgökçe \& Özçelik 2004; Simsek \& al. 2004; Kargığlu \& al. 2008; Öztürk \& Dinç 2005; Satıl \& al. 2008; Ezer \& Arisan 2006; Çakılcığlu \& Türkoğlu 2010). However, in Ağri province (eastern Turkey) only one ethnobotanical work has been carried out in limited areas and there is a need now to update this information (Gümüs 1994). Therefore, the aim of this paper is to compile the ethnobotanical information about the gathering and consumption of wild edible plant species in the Ağr1 province (Turkey) and provide a picture of their current knowledge and utilization.

\section{MATERIALS AND METHODS}

\section{The study area}

The findings for edible wild plants were collected in seven of the eight districts of the Ağr1 province, namely, Diyadin, Doğubayazıt, Eleşkirt, Hamur, Patnos, Taşlıçay and Tutak (Fig. 1), a region with an old traditional background in the consumption of these plant species. The Ağrı province is situated in eastern Anatolia Region of Turkey between the latitudes $38^{\circ} 59^{\prime}-40^{\circ} 02^{\prime} \mathrm{N}$ and longitudes $42^{\circ} 15^{\prime}-44^{\circ} 36^{\prime} \mathrm{E}$. It covers a total land area of $11,520 \mathrm{~km}^{2}$ with a human population estimated at about 540,000 . The climate in central districts is generally continental. According to the data from meteorological stations (Ağrı, Doğubayazıt and Patnos), which perform long term observations in Ağr1 (1960-2012), the annual average temperatures of the province vary between $6.2^{\circ} \mathrm{C}$ and $9.2^{\circ} \mathrm{C}$. The temperature in Ağrı may rise to $39.9^{\circ} \mathrm{C}$ in August and go down to $-45.6^{\circ} \mathrm{C}$ in January. The number of frosty days is 160.7 days, and mean annual rainfall is $521.8 \mathrm{~mm} / \mathrm{yr}$.

\section{Site selection and survey}

One village of each district was selected for an exhaustive biodiversity inventory based on their altitude and vegetation cover (Fig. 1). The spatial extent of the villages is highly variable and so the villages were determined with help of Development Agents and agricultural specialists in study areas. In each village, we started by inventorying these plant species. Five different villages in each district of the study area were visited for the ethnobotanical interviews (for all 7 districts $=$ in total 35 villages or small towns).

The study was carried out between 2014 and 2015 (from April to October). We carried out fieldwork to elaborate the inventory about wild edible plants, and also interviewed native elders who were familiar with these plants. Data were collected through open in-depth interviews with local elders (Martin 2014). Elderly and experienced people who lived in this region for many years and who knew the plants very well were favoured. Older women were preferred since they are more knowledgeable about edible wild plants than men. Ten informants were interviewed in each village and therefore 350 informants $(7 * 5 * 10=350)$ were recruited $(290$ female, 60 male; average age 65$)$.

We asked native elders to list all the wild food plants of the region and, for each wild edible plant species listed, to indicate all relevant knowledge about its consumption and gathering: present and past use, processing techniques and mode of consumption. Knowledge regarding wild edible plants was categorized according to Kadığlu \& al. (2016): Turkish vernacular name, part of the plant used (whole plant, leaf, stem, shoot, root, tuber, exudates, flower, seed and fruit), traditional preparation for consumption and consumption time. Wild food plant uses were organized under seven food usecategories: vegetables (including the subcategories cooked, raw, and pickles), spices, beverages, seeds, fruits, exudates and subterranean parts.

The identifications of the reported wild edible plants are based on Davis \& al. (1988) and Davis (1965-1985). Identifications were made by the Prof. Dr. Ali Kandemir. Two specimens of each wild edible plant species accompanied by detailed information on the collection locality, the characteristics of the plant, vernacular names, native culinary uses, and wild edible plants meanings were deposited in the herbarium of the Turkey Seed Gene Bank (Ankara) center and the Erzincan Horticultural Research Institute.

\section{Data Analysis}

The Cultural Importance (CI) index (Tardío \& Pardode-Santayana 2008) was used to express the importance of the studied species:

$$
\mathrm{UV}_{\mathrm{s}}=\sum \mathrm{UR} / \mathrm{N}
$$

where $\mathrm{N}$ is the total number of informants interviewed in the survey (350) and UR is the number of informants that mention each use-category for the species. For example, in 


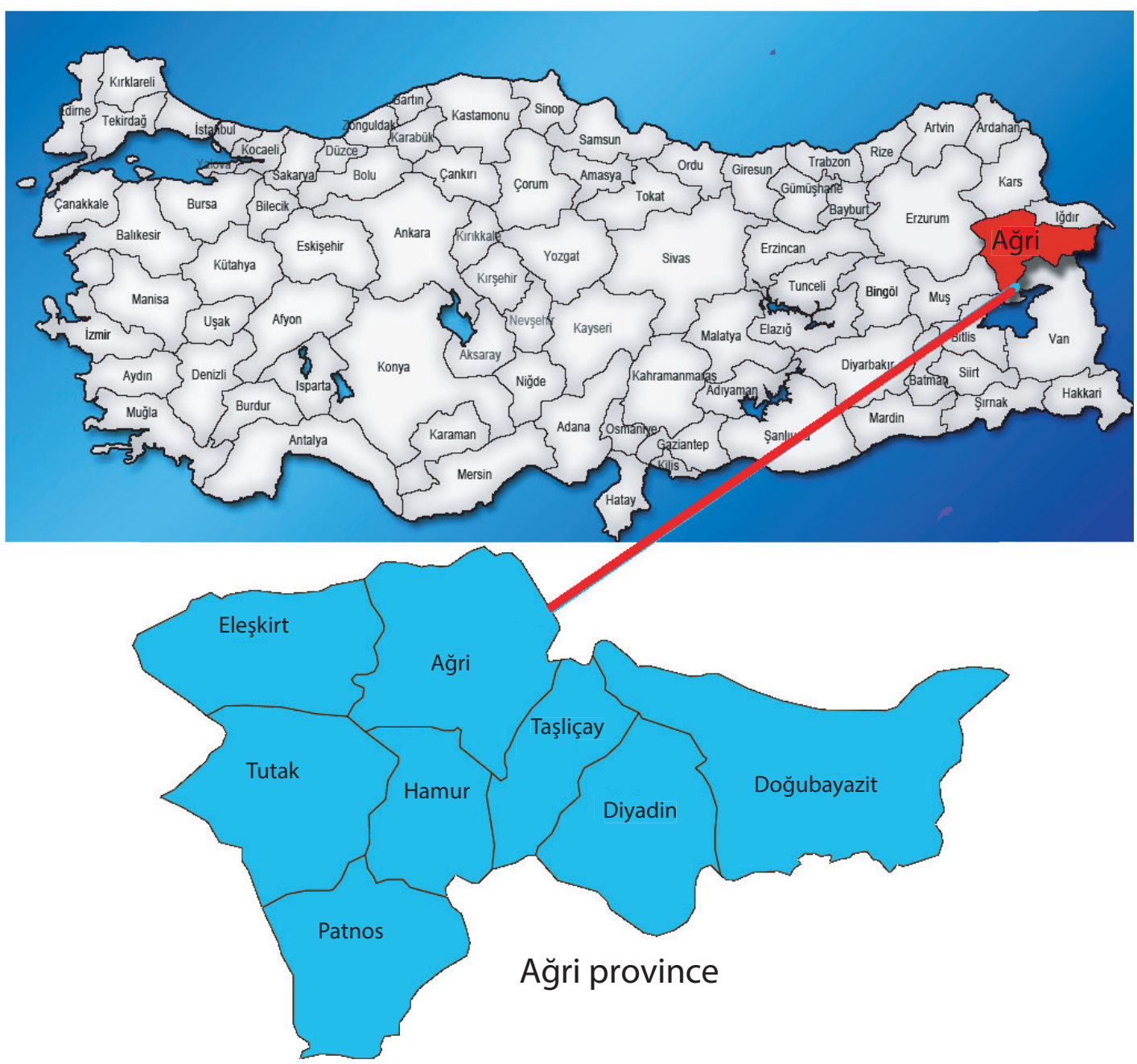

Fig. 1. Geographical location of the study region in Turkey.

the case of Anthriscus sylvestris (L.) Hoffm., 31 informants mentioned its use as a cooked vegetable, 48 as a raw vegetable, 61 as pickles, 14 as spice. Therefore, $\mathrm{CI}=(31+48+61+14) /$ $350=0.44$.

We also calculated the total CI of each use-category, adding the CI of all the species included in each category and the average $\mathrm{CI}$ of the category dividing the total CI of the category between the number of species reported for the category. For example, there are three species in the usecategory seeds (Cephalaria syriaca (L.) Schrad., Gundelia tournefortii L., and Vicia cracca L.). As these uses were mentioned by 46,35 and nine people, respectively, their CI as seed was $0.13,0.10$ and 0.03 . The total CI of seeds was 0.26 , the result of adding $0.13,0.10$ and 0.03 and the average CI of seeds was $0.09,0.26$ divided by three, i.e. the number of species of the use-category seeds.

\section{RESULTS AND DISCUSSION}

The ethnobotanical survey showed a great diversity of plant species used as wild foods in Ağrı. A total of 100 wild plant species and 25 families were documented and inventoried (Appendix 1). Among the 25 families, the four most important were Asteraceae (17 species), Lamiaceae (14 species), Apiaceae (12 species), and Polygonaceae (10 species). The remaining 21 families have from four (Brassicaceae, Amaranthaceae) to one species (Araceae, Arum rupicola Boiss; Caprifoliaceae, Cephalaria syriaca; Caryophyllaceae, Silene vulgaris (Moench) Garcker var. vulgaris; Hypericaceae, Hypericum perfoliatum L.; Malvaceae, Malva neglecta Wallr.; Primulaceae, Primula auriculata Lam.; Urticaceae, Urtica dioica L.; and Xanthorrhoeaceae, Eremurus spectabilis. M.Bieb., respectively) (Figure 2).

Based on the CI, the most important species were (ordered by CI): Amaranthus retroflexus L. (0.98), Tragopogon porrifolius subsp. longirostris (Sch.Bip.) Greuter (0.98), Urtica dioica (0.98), Beta trigyna Walds. \& Kit. (0.97), Gundelia tournefortii L. (0.97), Mentha longifolia L. (0.97), Polygonum persicaria L. (0.97), Rumex scutatus L. (0.97), Anchusa leptophylla Roemer \& Schultes (0.94), Caltha palustris L. (0.93), Capsella bursa-pastoris L. (0.93), Silene vulgaris var. vulgaris (0.93), Rumex crispus 


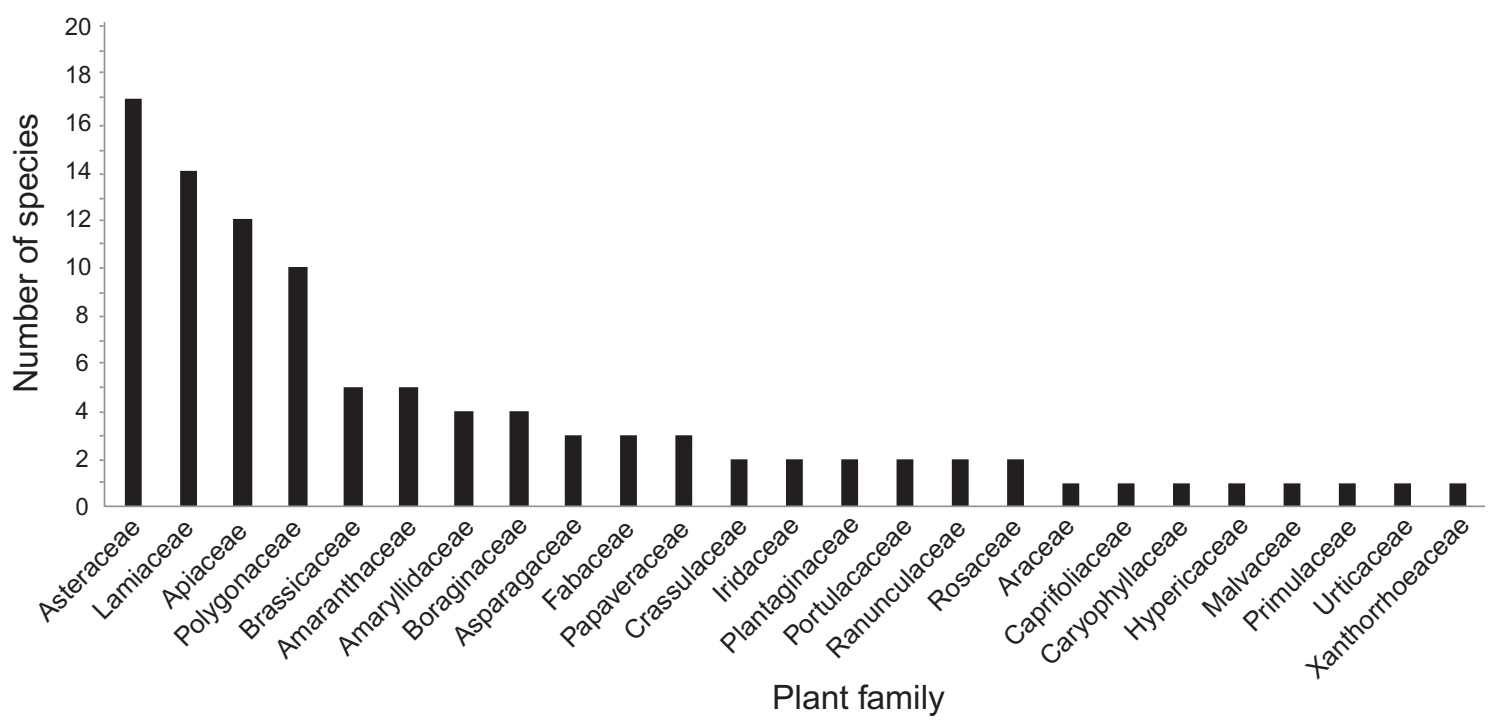

Fig. 2. Number of wild edible plants surveyed in the Ağrı province, distributed across plant families.

L. (0.92), Malva neglecta Wallr. (0.91), Nonea melanocarpa Boiss. (0.91), Rumex patientia L. (0.91), Thymus kotschyanus Boiss. \& Hohen. (0.90). All are vegetables, and most of them are eaten cooked. These data show that there is still a considerable number of species that are widely known, since most of them were cited by more than $90 \%$ of the people interviewed (Appendix 1).

Allium kharputense Freyn \& Sint., Alyssum peltarioides Boiss., Caltha palustris L., Ferula orientalis L., Rumex patientia, Scorzonera mollis M.Bieb. subsp szowitzii (DC) D.F.Chamb., and Stachys lavandulifolia Vahl, are some of the local wild edible plants used daily in the Ağrı region. They are loved as food and have not undergone any changes over the past decade (Appendix 1).

These species are gathered for self-consumption or are sold in local markets of the area. Some of these species are suffering overexploitation, so they are in danger of extinction due to unconscious or incorrect collecting techniques such as uprooting: Arum rupicola Boiss., Crocus biflorus subsp. tauri (Maw) B.Mathew, Rheum ribes L.

The vast majority of wild edible plants mentioned are frequently used as food in Turkey and other regions east of Turkey. However, several wild edible plants are only utilized in small areas of Turkey (e.g., Amaranthus retroflexus, Chenopodium album subsp. album, Eremurus spectabilis, Gundelia tournefortii, Malva neglecta, Mentha longifolia, Polygonum cognatum Meisn., Portulaca oleracea, Rheum ribes, Rumex crispus, Rumex scutatus, Scorzonera cana (C.A Meyer) Griseb. var. jacquiniana (W.Koch) Chamberlain, Tragopogon dubius Scop., and Urtica dioica (Cakilcioglu \& Turkoglu 2010; Özgen \& al. 2004; Ugulu \& al. 2009; Ezer \& Arısan 2006; Kırbağ \& Zengin 2006; Akan \& al. 2008; Arı \& al. 2015).

The use-category that included most plants was vegetables (91 taxa), followed by spices (19), beverages (16),
Table 1. Number of wild edible plant species and cultural importance of the use-categories and subcategories in the Ağrl province, Turkey.

\begin{tabular}{lcc}
\hline Use-category/subcategory & $\begin{array}{c}\text { Number of } \\
\text { species }\end{array}$ & $\begin{array}{c}\text { Cultural Importance } \\
\text { (CI total/average CI) }\end{array}$ \\
\hline Vegetables (VEG) & 91 & $42.84 / 0.47$ \\
Cooked (VEG) & 61 & $28.3 / 0.46$ \\
Raw (VEG) & 48 & $11.65 / 0.24$ \\
Pickles (VEG) & 9 & $2.89 / 0.32$ \\
Spices (SPI) & 19 & $5.38 / 0.38$ \\
Beverage (BEV) & 16 & $2.21 / 0.14$ \\
Subterranean parts (SUB) & 5 & $1.46 / 0.29$ \\
Fruits (FRU) & 3 & $1.52 / 0.51$ \\
Seeds (SEE) & 3 & $0.26 / 0.09$ \\
Exudates (EXU) & 2 & $0.32 / 0.16$ \\
\hline
\end{tabular}

subterranean parts (5), fruits (3), seeds (3), and exudates (2). The highest CI was for vegetables (total 42.84; cooked 28.3, raw 11.65, pickles 2.89), followed by spices (5.38), beverages (2.21), fruits (1.52), subterranean parts (1.46), exudates (0.32) and seeds (0.26). However, the highest average CI was for fruits $(0.51)$, followed by cooked vegetables $(0.46)$, raw vegetables $(0.24)$, spices $(0.28)$ and subterranean parts (0.29) (Table 1).

\section{Vegetables}

The most diverse use-category, with 91 species, was clearly vegetables. The high global CI of the category (42.84) and its high average (0.47) indicate that they are also the most widely used. As in previous studies, our results confirm the high diversity and intensive use of wild vegetables in east Turkey (Özgen \& Kaya 2004; Özgökçe \& Özçelik 2004; Kırbağ \& Zengin 2006; Akan \& al. 2008; Cakilcioglu \& Turkoglu 2010; Çakılcığlu \& al. 2010; Kadığlu \& al. 2016, 2020). 
Many of these vegetables are rich in valuable nutrients. For instance, Malva neglecta, eaten cooked or raw, is rich in vitamins A, B and C (Yeşil \& al. 2019). It has substantial local value as a vegetable (CI cooked: 0.8 and $\mathrm{CI}$ raw 0.11$)$ both in bordering countries and Turkey (Yeşil \& Akalın 2010; Pieroni $\&$ al. 2017; Yeşil \& al. 2019). As in the other parts of Turkey and in bordering countries, roots, young stems and petioles of Gundelia tournefortii, a good source of vitamins A, C and E are consumed cooked or raw in the study region (Şimşek \& al. 2004; Yeşil \& Akalın 2010; Karaaslan \& al. 2014; Ahmad \& al. 2015; Pieroni \& al. 2017; Yeşil \& al. 2019).

Most species are gathered in spring (mainly May and June), although there are also species that can be gathered earlier (e.g., Crocus biflorus subsp. tauri young leaves are consumed in March and April), later (e.g., Rheum ribes flower stems are eaten in July) or even all year round (e.g., Stachys lavandulifolia Vahl., Ziziphora clinopodioides Lam.). The plant parts most commonly used are young leaves and shoots. They are usually eaten fresh, mainly cooked (61 species), or raw (48). Besides nine species are preserved in pickles. The use-category cooked vegetables is clearly the most important (total CI 28.3, average CI 0.46). For instance, five of the species with the highest CI values are only consumed cooked (i.e., Amaranthus retroflexus, Beta trigyna Walds. \& Kit., Polygonum persicaria, Tragopogon porrifolius subsp. longirostris (Sch. Bip.) Greuter). The tops of the shoots, leaves and shoots are eaten cooked, stirred with olive oil and fried in oil with chili or garlic and different spices mixed with other wild vegetables.

An interesting group of cooked vegetables are those used to prepare dolma, an important component of Turkish cuisine inherited from the Ottomans. Dolma consists of stuffed vegetables like eggplant or stuffed peppers. They are usually stuffed with rice, meat and bulgur (chopped wheat). Big leaves of Heracleum trachyloma Fisch. \& C.Mey, Plantago major L., several Rumex species (R. alpinus L., R. crispus L., $R$. obtusifolius L. subsp. subalpinus (Schur) Celak., R. patientia), and Salvia verticillata $\mathrm{L}$. subsp. verticillata are also used for wraping dolma. Besides, young leaves of Eremurus spectabilis are used in stews that are added to the filling of dolma.

There are also species that are both eaten cooked and raw (e.g., Scorzonera mollis subsp. szowitzii, Tragopogon aureus Boiss.). Besides a very important number of species are only eaten raw, being Rumex scutatus the species with highest CI (0.97). Some of them are brought home to prepare salads (e.g., Portulaca oleracea L., Rumex scutatus, Teucrium chamaedrys L.) and others are consumed without any preparation. For instance, the fresh leaves of Allium kharputense Freyn \& Sint., Allium gramineum K.Koch (Körmen, Sir, Sirim), Arctium tomentosum Mill., Caltha palustris, Plantago major, Rumex crispus, Rumex obtusifolius subsp. subalpinus, Rumex patientia, and Xanthogalum purpurascens Lallem. are consumed raw at home. On the other hand, the fresh leaves and fresh shoots of other species are consumed raw in the field (e.g., Allium atroviolaceum Boiss., Anthriscus nemorosa (M.Bieb) Spreng., Carduus nutans L., Heracleum trachyloma, Hylotelephium telephium (L.) H.Ohba, Onopordum acanthium L., Rheum ribes, Scorzonera cana (C.A.Meyer) Griseb. var. jacquiniana (W.Koch) D.F.Chamb., Scorzonera mollis subsp szowitzii, Sempervivum minus Turril ex Wale., Tragopogon aureus, and Tragopogon dubius Scop.).

Besides leaves and young shoots, flowers are also consumed. This is the case of the young flowers of Iris persica, that are valued for their mild taste. Interestingly, they are known as the heralds of the arrival of spring (Yeşil \& al. 2019). Other interesting species is Echinops pungens Trautv. which immature receptacle of the inflorescences are consumed in a similar way as the heart of the artichokes.

The other important category of vegetables are those used to elaborate pickles. While only nine species are used, its average CI is high (0.32). Their shoots are placed in a sterilized jar along with salt, as well as spices, and are then allowed to mature until the desired taste is obtained. In general, tartness has a very important place in making pickles for people in the region, as the tart taste of these plants is perceived as a special flavor in the sense of "a different taste" and "good for the food". For instance, Ferula orientalis L. and Prangos platychlaena Boiss. are especially valuable for the inhabitants of the Ağr1 region and their taste is described as "tart or sour" (Heliz or Çakşur in Ağr1). While Ferula orientalis (0.75) and Prangos platychlaena (0.78) are culturally important species in the study region, their usage is not very common in other areas of Turkey (Kadıoğlu \& al. 2016, 2020).

Taste has an important place in the selection of wild edibles for local communities and people pay attention to collect tart/sour wild edible plant species to obtain a balanced taste of the meals. On the other hand, the taste of plants or foods is often an important criterion for categorizing, characterizing and detecting food plants (Johns 1986; Nebel 2001; Grivetti 1981).

\section{Spices}

Plants used for seasoning food are also commonly used. Nineteen species with a total CI of 5.38 and an average CI of 0.28 were reported, being Mentha longifolia $\mathrm{L} .(\mathrm{CI}=0.89)$, Thymus sipyleus Boiss. (0.63) and Ziziphora clinopodioides Lam. (0.58) the species with highest CI. These species are used freshly in salads called Turkish Shepherd's Salad, Rezepte, Mamzana. Additionally, dried parts of them are cooked and consumed in yogurt soups such as Turkish Yogurt Soup. Many of them are members of the Lamiaceae family and are also consumed raw and to prepare herbal teas (e.g., Nepeta italica L., Satureja hortensis L.). An interesting group of six species are used to flavor cheese, mainly Allium species and several Apiaceae (e.g., Anthriscus sylvestris, Chaerophyllum bulbosum L.). 


\section{Beverages}

In the studied region, 16 taxa were used for preparing herbal teas, being Alyssum peltarioides Boiss the most cited species (0.49). All their parts are consumed as a tea, but also as salad and spice. Another widely consumed beverage is the sherbet (diluted syrups produced with the addition of sugar) made from the flowers of Papaver argemone L. (0.3). Young shoots and leaves of Hypericum perfoliatum L. (0.23), Mentha longifolia L. (0.06), Nepeta racemosa Lam. (0.03), Nepeta italica L. (0.07), Rosa pimpinellifolia L. (0.18), Salvia multicaulis Vahl. (0.03), Satureja hortensis L. (0.28), Stachys lavandulifolia Vahl. (0.04), Thymus kotschyanus (0.07), Thymus pubescens Boiss. \& Kotschy ex Celak. (0.11), Thymus sipyleus (0.06), and Ziziphora clinopodioides Lam. (0.03) are also used as herbal teas as in other Turkish regions (Özgen \& Kaya 2004; Özgökçe \& Özçelik 2004; Kırbağ \& Zengin 2006; Akan \& al. 2008; Kadığlu \& al. 2016, 2020). Another interesting common beverage in Ağrı, also previously cited, is the herbal tea prepared with flowers of Iris persica $(0.06)$ (Akgül \& al. 2018).

\section{Subterranean parts}

Roots and tubers from five species are eaten in the region, being Arctium tomentosum the most cited (0.66). Its root collar is peeled and consumed raw. The roots of two thistles (Cirsium rhizocephalum C.A Mey., 0.26; Onopordum acanthium, 0.21) are consumed after cooking and the roots of Lathyrus tuberosus L. (0.06) and the corms (bulbiferous tubers) of Crocus biflorus subsp. tauri (0.27) raw.

\section{Fruits}

The fruits of three taxa, including Lathyrus tuberosus L. (0.27), Rosa pimpinellifolia L. (0.37), and Rubus idaeus L. (0.87) are consumed raw. The fruits of Rosa pimpinellifolia are especially known for their effectiveness in colds and for strengthening the body's defenses against infection (Baytop 1999). Furthermore, fruits of Rosa pimpinellifolia are rich in minerals $(\mathrm{C}, \mathrm{P}, \mathrm{A})$, vitamins $(\mathrm{B} 1, \mathrm{~B} 2, \mathrm{E}, \mathrm{K})$, organic acids, sugar, tannins, pectin, essential oils (Demir \& Özcan 2001; Mehmet \& al. 2018). In addition, Rubus idaeus L. fruits are used to elaborate jams and the leaves of Rosa pimpinellifolia are dried and used to prepare a drink.

\section{Seeds}

The use-category seeds includes three species. From our knowledge, Cephalaria syriaca $(0.1)$ has been recorded as edible in the present study for the first time. The seeds are ground and used for making bread mixed with wheat flour. Gundelia tournefortii seeds (0.13) are cooked and consumed as grain/kernel substitutes. The seeds of the plant are dried with a paper towel and placed in a bowl. Then olive oil and salt are added. It is spread on a baking sheet and baked for 5-10 minutes until browned and crispy. Given their lipid content they have been studied as a source of edible oil
(Khanzadeh \& al. 2012). Finally, Vicia cracca raw seeds are eaten as in southeastern Turkey (Yeşil \& al. 2019).

\section{Exudates}

In the study area, the latex of Gundelia tournefortii (0.25) roots and Scorzonera latifolia (Fisch. \& C. A. Mey.) DC. (0.07) shoots are used to prepare chewing gum. These findings are similar to our previous results (Kadığlu \& al. 2016, 2020).

\section{Plant names}

A very rich number of plant names was obtained. Local phytonyme of wild edibles consisted in 157 local names, 145 simple (e.g., söğütotu, kuşekmeği) and 12 complex names (e.g., yabani sakız, yer çileği) (Appendix 1). The average number of names by species was 2.13 , having most species one, two or three names $(35,29$ and 25 species respectively). Generic names that are used for several species were also common. For instance kımı and mendek were applied to three different morphologically similar Apiaceae species (Anthriscus sylvestris, Chaerophyllum bulbosum, Ch. crinitum Boiss.), and kekik to four Lamiaceae species (Thymus kotschyanus, Thymus pubescens, Thymus sipyleus, Ziziphora clinopodioides).

The language of the vast majority of the wild edible plant species names recorded is Turkish (e.g., evelik, Rumex crispus, Rumex patientia; tirşo, Rumex scutatus, Rumex tuberosus subsp. horizontalis; işgın, Rheum ribes; isırgan, Urtica dioica L.; çiriş, Eremurus spectabilis M. Bieb.). Kurdish is also spoken in the area and four Kurdish names were mentioned: tirşo, Rumex crispus, Rumex patientia, Rumex scutatus, Rumex tuberosus subsp. horizontalis; silgok, Beta trigyna, Beta lomatogona Fisch. \& C.A. Mey; sirim, Allium sp., Allium atroviolaceum, Allium gramineum; silmask, Chenopodium album subsp. album).

The wild edible plant species utilized in Ağrı are called by the same or very similar local names in different regions of Anatolia (e.g., Mentha longifolia, yarpuz; Gundelia tournefortii, kenger, Malva neglecta, ebegümeci; Polygonum cognatum, madımak; Rheum ribes, işkın; Urtica dioica, isırgan; Rumex scutatus, ekşime; Rumex crispus L., evelik; Eryngium billardierei F.Delaroche, boğa dikeni) (Yücel \& Tülükoğlu 2000; Sarper \& al. 2009; Ar1 \& al. 2015; Çakilcioglu \& Turkoglu 2010). This similarity reflects a wide sharing of ethnobotanical knowledge in the region.

There are also plants whose local names in Ağrı are different from other areas of Turkey (e.g., Silene vulgaris var. vulgaris, cıvrıncık, gelin parmağı; Capsella bursa-pastoris, çoban çantası; Ononis spinosa L., kayışkıran; Salvia multicaulis, adaçay1; Teucrium chamaedrys, mayasılotu; Teucrium polium L., ülper yavşanı, acı ot; Papaver rhoeas L., gelincik; Rumex scutatus, kuzukulağ1; Portulaca oleracea, semizotu, temizlik out; Chenopodium album subsp. album, sar1 sirken; Beta trigyna, kır ıspanağı; Rumex patientia, ilibada; Polygonum 
cognatum, çoban ekmeği; Urtica dioica, gezgezik; Echium vulgare L., sormuk) (Çakilcioglu \& Turkoglu 2010; Ar1 $\&$ al. 2015). This situation could be due to the changing demographics of the young population or domestic people, i.e. residents who migrated to different provinces were replaced by migrants from different cities of Turkey. Hence, the regional people pattern changed progressively and finally such a situation modified the regional population culture.

Additionally, because villagers in the local community are usually migrating to large cities or towns and benefiting from the facilities of modern agriculture or different food products, the heritage of traditional wild edible plant species information is decreasing dramatically. Moreover, the younger generation in the local community tends to migrate to large cities in an effort to earn more money and find steady jobs. Consequently, villages in the region are rapidly emptying of their new generations or young population and such a situation raises the danger of losing regional knowledge about wild edible plant species.

The results of our work indicate a very rich ethnobotanical knowledge about wild edible plant species in rural areas of Ağrı. It is vital to document local usages as food through further studies before it is too late. Some of the wild edible plant species of Ağrı are endangered by over grazing, use of chemical herbicides in farming, inattentive picking of edible wild plant species to generate revenue, and expansion of new agricultural lands. Given the nutritional interest of many of these species, the documented data could be used as baseline information for further investigations on nutritional contents, as they could have the potential to become valuable nutrition sources for people. These uses could help to promote the sustainable development of the area, once inappropriate gathering techniques are excluded.

\section{ACKNOWLEDGEMENTS}

We would like to thank Prof. Dr. Ali Kandemir for his assistance in the identification of the plants and the local people who shared their botanical knowledge. We are also grateful to the Ağr1 people for their hospitality. This research work was supported by General Directorate of Agricultural Research and Policies, Scientific Research Project -SRP, (Project no; TAGEM/BBAD/11/06/01/006) appropriated to Erzincan Horticultural Research Institute, Turkey. Authors Contributions: ZK designed the study. OK and ZK wrote the manuscript and interpreted the results. KC, NNK and HV were responsible for the performance of the research, collection, data analysis and interpretation.

\section{REFERENCES}

Ahmad S.A. \& Askari A.A. 2015. Ethnobotany of the Hawraman region of Kurdistan Iraq. Harvard Papers in Botany 20: 85-9.

Abbet C., Mayor R., Roguet D., Spichiger R., Hamburger M. \& Potterat, O. 2014. Ethnobotanical survey on wild alpine food plants in lower and central Valais (Switzerland). Journal of Ethnopharmacology 151: 624-634.

Akgül A., Akgül A., Şenol S.G., Yıldırım H., Seçmen Ö. \& Doğan Y. 2018. An ethnobotanical study in Midyat (Turkey), a city on the silk road where cultures meet. Journal of Ethnobiology and Ethnomedicine 14: 12.

Akan H., Korkut M.M. \& Balos M.M. 2008. An ethnobotanical study around Arat Mountain and its surroundings (Birecik, Sanliurfa). Firat University Journal of Science and Engineering 20: 67-81.
Arı S., Temel M., Kargığlu M. \& Konuk M. 2015. Ethnobotanical survey of plants used in Afyonkarahisar-Turkey. Journal of Ethnobiology and Ethnomedicine 11: 84.

Baytop T. 1999. Herbal medicine in Turkey, past and present. İstanbul: Nobel Tıp Kitabevleri Yayınları (in Turkish).

Behre K.E. 2008. Collected seeds and fruits from herbs as prehistoric food. Vegetation History and Archaeobotany 17: 65-73.

Bharucha Z. \& Pretty J. 2010. The roles and values of wild foods in agricultural systems. Philosophical Transactions of the Royal Society B: Biological Sciences 365: 2913-2926.

Blanco-Salas J., Gutiérrez-García L., Labrador-Moreno J. \& Ruiz-Téllez T. 2019. Wild plants potentially used in human food in the Protected Area "Sierra Grande de Hornachos" of Extremadura (Spain). Sustainability 11: 456.

Block G. 1991. Dietary guidelines and the results of food consumption surveys. The American Journal of Clinical Nutrition 53: 356S-357S.

Çakılcıoğlu U. \& Turkoglu I. 2010. An ethnobotanical survey of medicinal plants in Sivrice (Elazığ-Turkey). Journal of Ethnopharmacology 132: $165-175$.

Çakılcıoğlu U., Şengün M.T. \& Türkoğlu İ. 2010. An ethnobotanical survey of medicinal plants of Yazıkonak and Yurtbaşı districts of Elazı̆ province, Turkey. Journal of Medicinal Plants Research 4: 567-572.

Couladis M., Tzakou O., Verykokidou E. \& Harvala C. 2003. Screening of some Greek aromatic plants for antioxidant activity. Phytotherapy Research 17: 194-195.

Davis P.H. (ed.). 1965-1985. Flora of Turkey and the East Aegean Islands, vol. 1-9. Edinburgh University Press, Edinburgh.

Davis P.H., Mill R.R., Tan K. (eds.). 1988. Flora of Turkey and the East Aegean Islands, vol. 10. Edinburgh University Press, Edinburgh.

Demir F. \& Özcan M. 2001. Chemical and technological properties of rose (Rosa canina L.) fruits grown wild in Turkey. Journal of Food Engineering 47: 333-336.

Ertuğ, F. 2004. Wild edible plants of the Bodrum area (Muğla, Turkey). Turkish Journal of Botany 28: 161-174.

Ezer N. \& Arisan Ö.M. 2006. Folk medicines in Merzifon (Amasya, Turkey). Turkish Journal of Botany 30: 223-230.

Gümüş İ. 1994. The local names and uses of some useful plants grown in Ağrı Province (Ağrı Yöresinde Yetişen Bazı Faydalı Bitkilerin Yerel Adları ve Kullanışları). Turkish Journal of Botany 18: 107-112. (In Turkish)

Grivetti L.E. 1981. Cultural nutrition: Anthropological and geographical themes. Annual Review of Nutrition 1: 47-68.

Guil Guerrero J.L., Giménez Martinez J.J. \& Torija Isasa M.E. 1998. Mineral nutrient composition of edible wild plants. Journal of Food Composition and Analysis 11: 322-328.

Hasler C.M. 2002. Functional foods: benefits, concerns and challenges a position paper from the American Council on Science and Health. The Journal of Nutrition 132: 3772-3781.

Heinrich M., Müller W.E. \& Galli C. (eds.). 2006. Local Mediterranean food plants and nutraceuticals (Vol. 59). Karger Medical and Scientific Publishers.

Hummer K.E. 2013. Manna in winter: indigenous Americans, huckleberries, and blueberries. Hortscience 48: 413-417.

Johns T. 1986. Chemical selection in Andean domesticated tubers as a model for the acquisition of empirical plant knowledge. In Etkin N. (ed.), Plants in indigenous medicine and diet: Behavioural approaches (pp. 266-288). New York: Redgrave.

Kalle R. \& Soukand R. 2013. Wild plants eaten in childhood: a retrospective of Estonia in the 1970s-1990s. Botanical Journal of the Linnean Society 172: 239-253. 
Khanzadeh F., Haddad Khodaparast M.H., Elhami Rad A.H., Rahmani F. 2012. Physiochemical properties of Gundelia tournefortii L. seed oil. Journal of Agricultural Science and Technology 14: 1535-1542.

Karaaslan Ö., Çöteli E. \& Karataş F. 2014. Investigation of amounts of A, E, C vitamins with malondialdehyde and glutathione in plant Gundelia tournefortii. Erzincan Üniversitesi Fen Bilimleri Enstitüsü Dergisi 7-2: $159-68$.

Kargığlu M., Cenkci S., Serteser A., Evliyaoğlu N., Konuk M., Kök M.Ş. \& Bağc1 Y. 2008. An ethnobotanical survey of inner-West Anatolia, Turkey. Human Ecology 36: 763-777.

Kırbağ S. \& Zengin F. 2006. Antimicrobial activities of some medical plants in Elazığ region. Yüzüncü Yll University Journal of Agricultural Sciences 16: $77-80$.

Kadıŏlu Z., Çukadar K., Kandemir A., Kalkan N.N., Vurgun H. \& Dönderalp V. 2020. Kars İlinde Sebze Olarak Tüketilen Yabani Bitki Türlerinin Tespiti ve Kullanım Șekilleri. Anadolu Ege Tarımsal Araștırma Enstitüsü Dergisi 30: $11-32$.

Kadıŏlu Z., Cukadar K., Kandemir A., Aslay M., Kalkan N.N., Vurgun H. \& Ertürk N. 2016. Erzincan ve Erzurum illerinde sebze olarak tüketilen yabani bitki türlerinin tespiti ve kullanım şekilleri. Uluslararası Erzincan Sempozyumu. 28 Eylül-01 Ekim 2016. Erzincan. s. 855-877.

Kadıoğlu Z., Çukadar K., Kandemir A., Kalkan N.N., Vurgun H. \& Dönderalp V. 2020. Kars İlinde Sebze Olarak Tüketilen Yabani Bitki Türlerinin Tespiti ve Kullanım Şekilleri. ANADOLU Ege Tarımsal Araştırma Enstitüsü Dergisi 30 11-32.

Leonti M., Nebel S., Rivera D. \& Heinrich M. 2006. Wild gathered food plants in the European Mediterranean: a comparative analysis. Economic Botany 60: 130-142.

Łukasz Ł., Zovko Končić M., Miličević T., Dolina K. \& Pandža M. 2013. Wild vegetable mixes sold in the markets of Dalmatia (southern Croatia). Journal of Ethnobiology and Ethnomedicine 9: 2.

Millenium Ecosystem Assessment. 2005. Ecosystems and Human Wellbeing: A Framework for Assessment. Island Press, Washington, D.C., USA.

Martin G.J. 2014. Ethnobotany: a methods manual. Springer.

Mehmet Ö.Z., Baltac1 C. \& Deniz İ. 2018. Gümüșhane Yöresi Kuşburnu (Rosa canina L.) ve Siyah Kuşburnu (Rosa pimpinellifolia L.) Meyvelerinin C Vitamini ve Şeker Analizleri. Gümüşhane Üniversitesi Fen Bilimleri Enstitüsü Dergisi 8: 284-292.

Nebel S. 2001. Arbereshe taste perception of wild food plants. Thesis M.Sc in Ethnobotany, University of Kent at Canterbury.

Nebel S., Pieroni A. \& Heinrich M. 2006. Ta chòrta: wild edible greens used in the Graecanic area in Calabria, Southern Italy. Appetite 47: 333-342.

Ogle B.M., Tuyet H.T., Duyet H.N. \& Dung N.N.X. 2003. Food, feed or medicine: the multiple functions of edible wild plants in Vietnam. Economic Botany 57: 103-117.

Özgen U. \& Kaya Y. 2004. Ethnobotanical studies in the villages of the district of Ilica (Province Erzurum), Turkey. Economic Botany 58: 691-696.

Özgökçe F. \& Özçelik H.A.S.A.N. 2004. Ethnobotanical aspects of some taxa in East Anatolia, Turkey. Economic Botany 58: 697.

Öztürk M. \& Dinç M. 2005. Ethnobotanical features of Nizip (Aksaray) district. The Herb Journal of Systematic Botany 12: 93-102.

Pardo-de-Santayana M., Tardío J., Blanco E., Carvalho A.M., Lastra J.J., San Miguel E. \& Morales R. 2007. Traditional knowledge of wild edible plants used in the northwest of the Iberian Peninsula (Spain and Portugal): a comparative study. Journal of Ethnobiology and Ethnomedicine 3: 27.

Pardo-de-Santayana M., Tardío J. \& Morales R. 2005. The gathering and consumption of wild edible plants in the Campoo (Cantabria, Spain). International Journal of Food Sciences and Nutrition 56: 529-542.
Pieroni A. 2008. Local plant resources in the ethnobotany of Theth, a village in the Northern Albanian Alps. Genetic Resources and Crop Evolution 55: $1197-1214$.

Pieroni A., Janiak V., Dürr C.M., Lüdeke S., Trachsel E. \& Heinrich M. 2002. In vitro antioxidant activity of non-cultivated vegetables of ethnic Albanians in southern Italy. Phytotherapy Research 16: 467-473.

Pieroni A., Nebel S., Quave C., Munz H. \& Heinrich M. 2002. Ethnopharmacology of liakra: traditional weedy vegetables of the Arbereshe of the Vulture area in southern Italy. Journal of Ethnopharmacology 81: $165-185$.

Pieroni A., Ahmed H.M. \& Zahir H. 2017. The spring has arrived: traditional wild vegetables gathered by Yarsanis (Ahl-e Haqq) and Sunni Muslims in Western Hawraman, SE Kurdistan (Iraq). Acta Societatis Botanicorum Poloniae 86: 3519.

Reyes-García V., Menendez-Baceta G., Aceituno-Mata L., Acosta-Naranjo R., Calvet-Mir L., Domínguez P., Garnatje T., Gómez-Baggethun E., MolinaBustamante M., Molina M., Rodríguez-Franco R., Serrasolses G., Vallès J. \& Pardo-de-Santayana M. 2015. From famine foods to delicatessen: Interpreting trends in the use of wild edible plants through cultural ecosystem services. Ecological Economics 120: 303-311.

Rivera D., Obón C., Inocencio C., Heinrich M., Verde A., Fajardo J. \& Palazón J.A. 2007. Gathered food plants in the mountains of Castilla-La Mancha (Spain): ethnobotany and multivariate analysis. Economic Botany 61: 269.

Sarper F., Akaydin G., Şimșek I. \& Yeșilada E. 2009. An ethnobotanical field survey in the Haymana district of Ankara province in Turkey. Turkish Journal of Biology 33: 79-88.

Satıl F., Akçiçek E. \& Selvi S. 2008. An ethnobotanical study in Madra Mountain (Balıkesir-İzmir) and vicinity. Research Journal of Biology Sciences 1: 31-36.

Schulp C.J., Thuiller W. \& Verburg P.H. 2014. Wild food in Europe: A synthesis of knowledge and data of terrestrial wild food as an ecosystem service. Ecological Economics 105: 292-305.

Simsek I., Aytekin F., Yesilada E. \& Yildirimli Ş. 2004. An ethnobotanical survey of the Beypazari, Ayas, and Güdül district towns of Ankara Province (Turkey). Economic Botany 58: 705-720.

Tapsell L.C., Hemphill I., Cobiac L., Sullivan D.R., Fenech M., Roodenrys S., Keogh J.B., Clifton P.M., Williams P.G., Fazio V.A. \& Inge K.E. 2006 Health benefits of herbs and spices: the past, the present, the future. Medical Journal of Australia 185(S4): S1-S24.

Tardío J. \& Pardo-de-Santayana M. 2008. Cultural importance indices: a comparative analysis based on the useful wild plants of Southern Cantabria (Northern Spain). Economic Botany 62: 24-39.

Tardío J., Pardo-de-Santayana M. \& Morales R. 2006. Ethnobotanical review of wild edible plants in Spain. Botanical Journal of the Linnean Society 152: $27-71$.

Tarwadi K. \& Agte V. 2003. Potential of commonly consumed green leafy vegetables for their antioxidant capacity and its linkage with the micronutrient profile. International Journal of Food Sciences and Nutrition 54: 417-425.

Trichopoulou A., Vasilopoulou E., Hollman P., Chamalides C., Foufa E., Kaloudis T., Kromhout D., Miskaki P., Petrochilou I., Poulima E., Stafilakis K. \& Theophilou D. 2000. Nutritional composition and flavonoid content of edible wild greens and green pies: A potential rich source of antioxidant nutrients in the Mediterranean diet. Food Chemistry 70: $319-323$.

Tumino R., Frasca G., Giurdanella M.C., Lauria C. \& Krogh V. 2002. Consumption of wild vegetables in the EPIC cohort of Ragusa (Sicily). In Riboli E. \& Lambert R. (eds.), Nutrition and lifestyle: Opportunities for cancer prevention (pp. 115-116). Lyon: International Agency for Research on Cancer. 
Turner N.J. \& Turner K. 2008. "Where our women used to get the food": cumulative effects and loss of ethnobotanical knowledge and practice; case study from coastal British Columbia. Botany 86: 103-115.

Ugulu I., Baslar S., Yorek N. \& Dogan Y. 2009. The investigation and quantitative ethnobotanical evaluation of medicinal plants used around Izmir province, Turkey. Journal of Medicinal Plants Research 3: 345-367.

Yeşil Y. \& Akalın E. 2010. The use of edible plants in Kürecik (Akçadağ/ Malatya). Turkish Journal of Pharmaceutical Science 41: 90-103.
Yeşil Y., Çelik M. \& Yılmaz B. 2019. Wild edible plants in Yeşilli (Mardin-Turkey), a multicultural area. Journal of Ethnobiology and Ethnomedicine 15: 52.

Yücel E. \& Tülükoglu A. 2000. Plants used as folk medicine in and around Gediz (Kütahya). Ekoloji 9: 12-14.

Zeghichi S., Kallithraka S., Simopoulos A.P. \& Kypriotakis Z. 2003. Nutritional composition of selected wild plants in the diet of Crete. In Simopoulos A.P. \& Gopalan C. (eds.), Plants in human health and nutrition policy, Vol. 91: 22-40. Basel: Karger. 


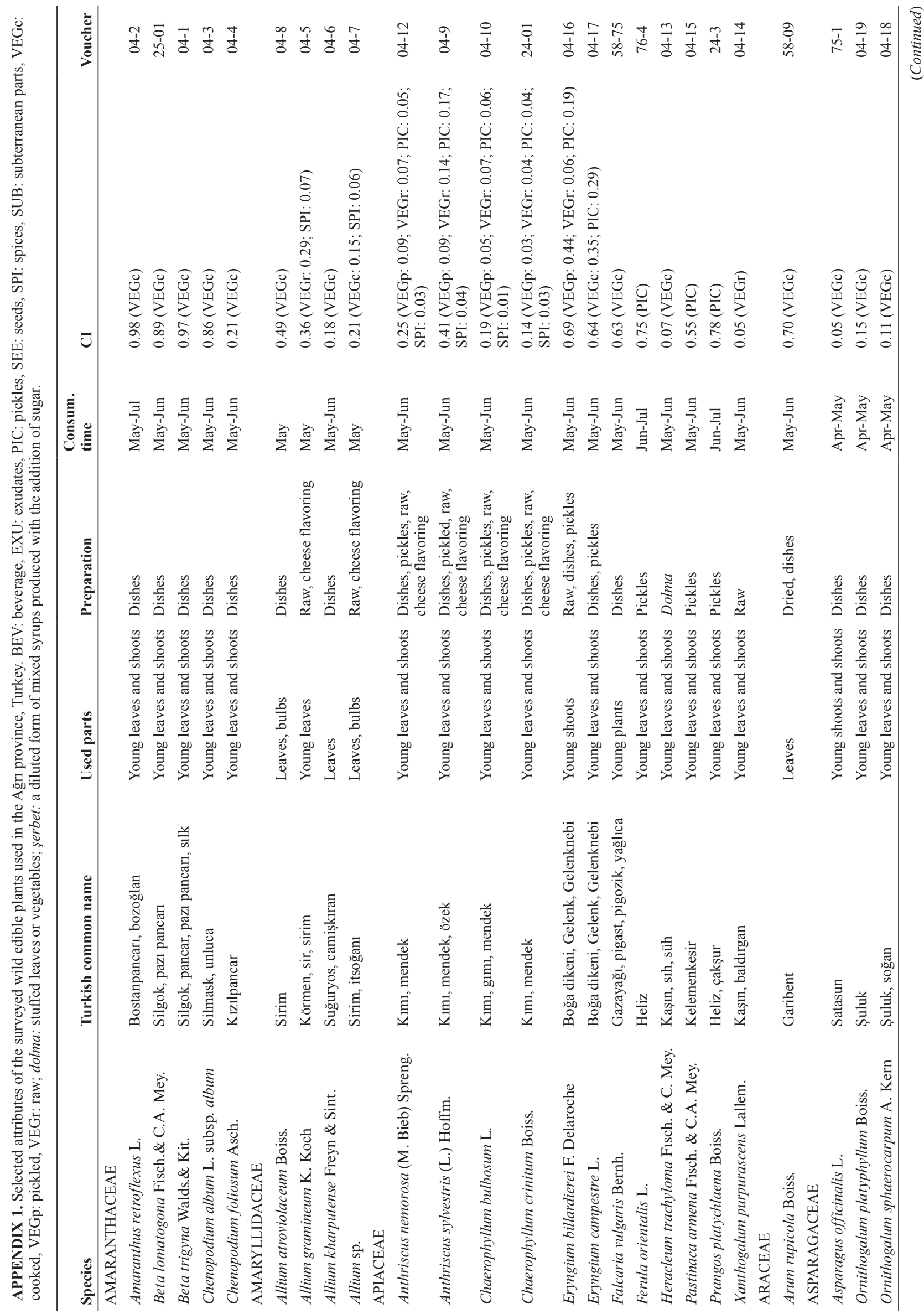




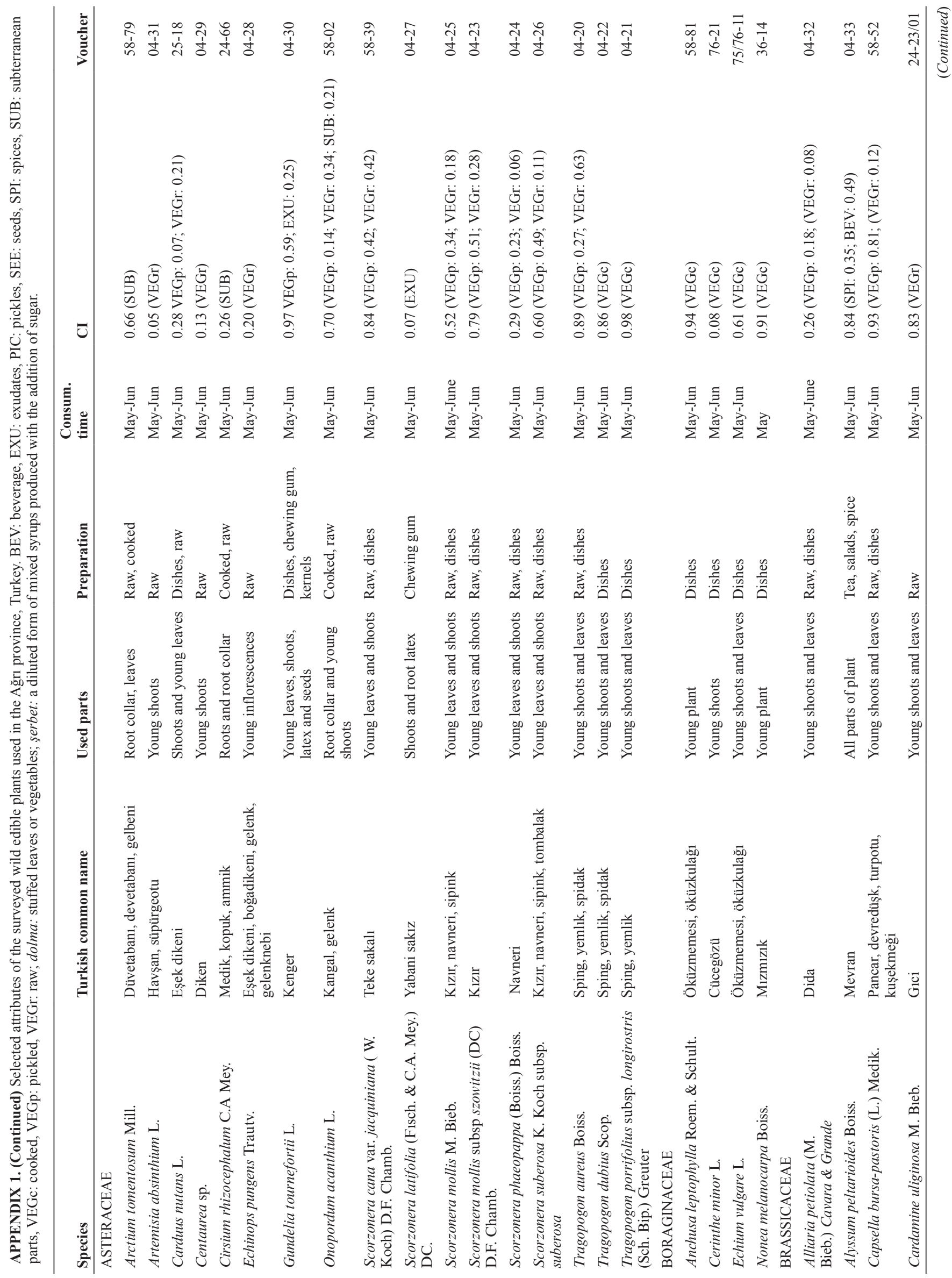




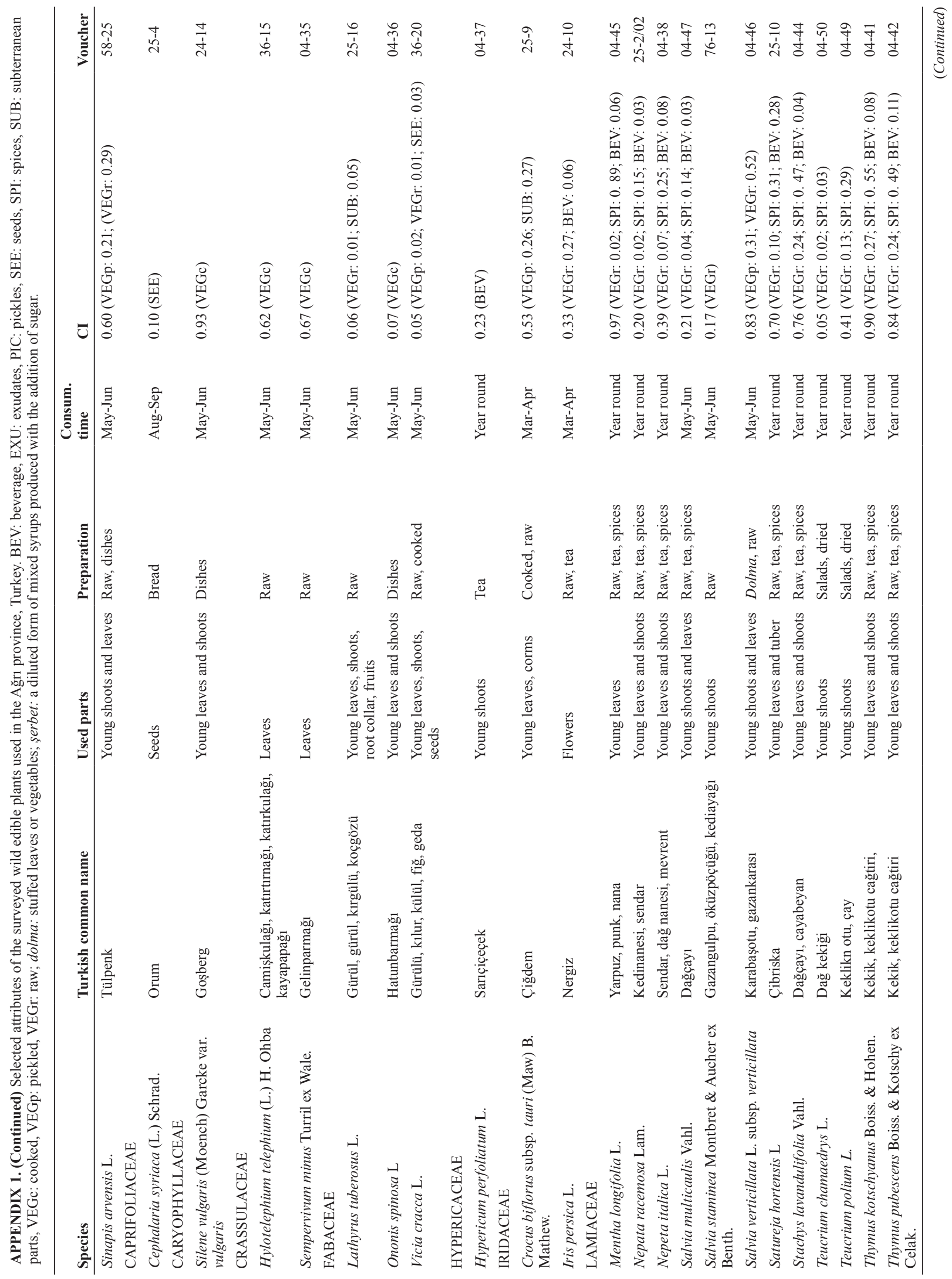




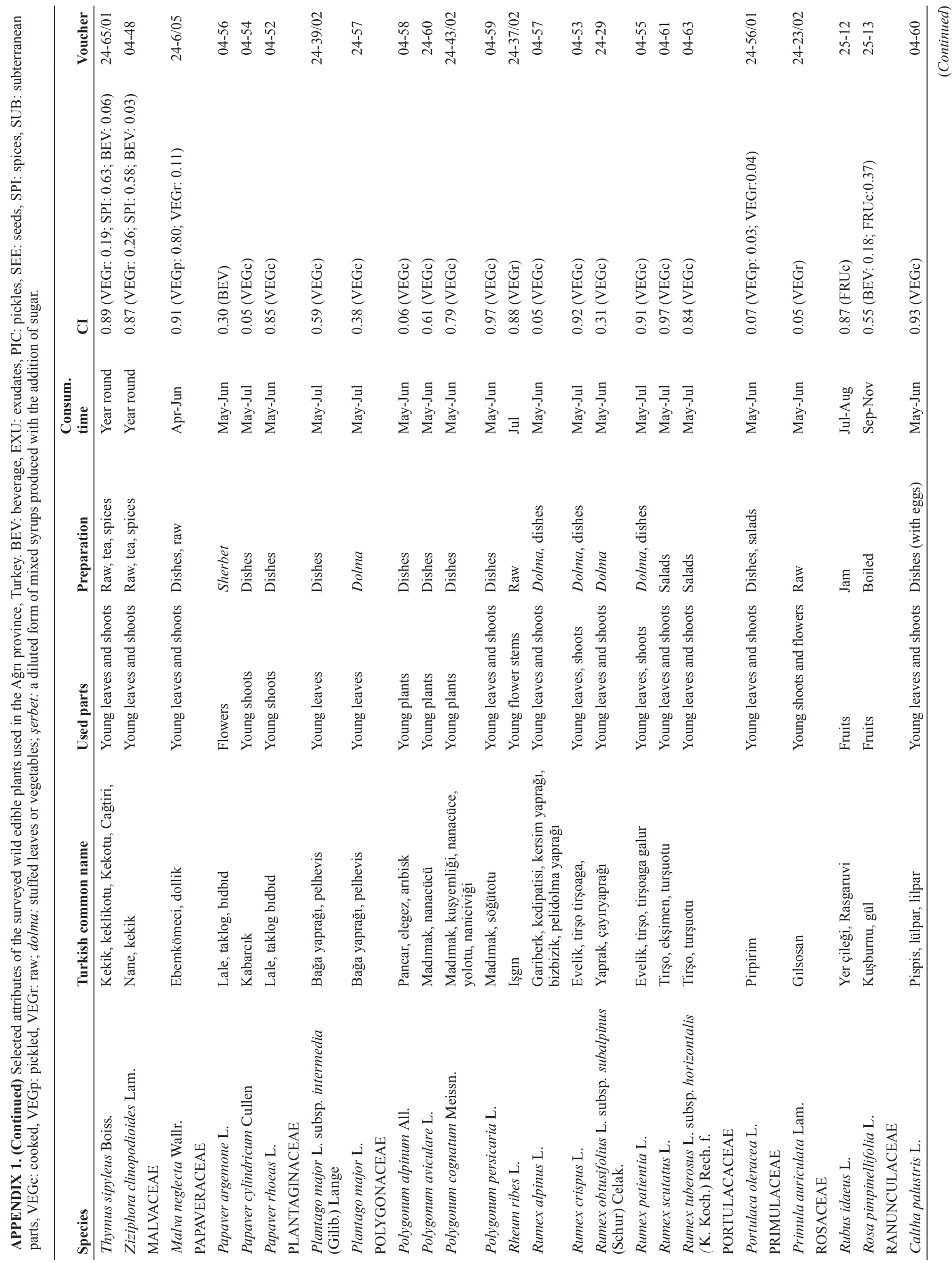




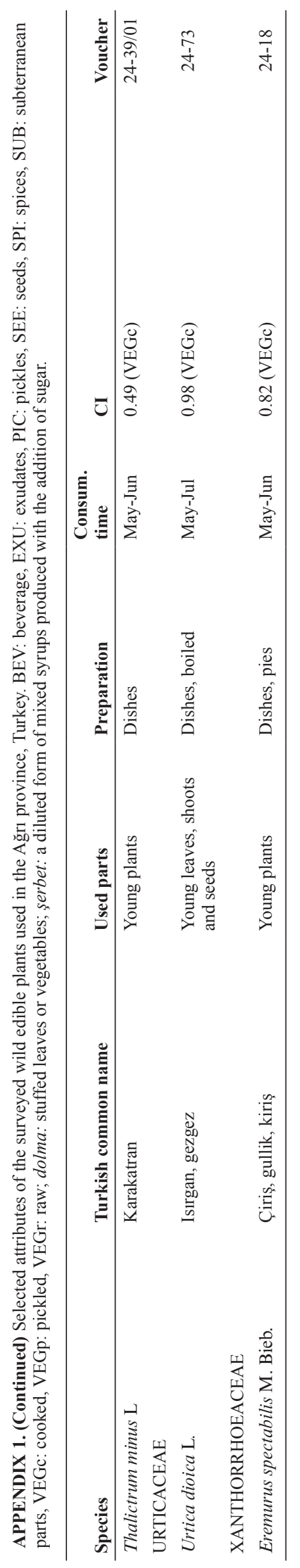

